\title{
System Dynamics Modeling on Integrated Supply Chain Management of Potato Agribusiness
}

\author{
${ }^{1}$ LUKMAN HAKIM, ${ }^{2}$ TOMY PERDANA \\ ${ }^{1}$ Fakultas Pertanian, Universitas Syiah Kuala, Jl. Tgk. Hasan Krueng Kalee No. 10, Banda Aceh 23111 \\ 2 Fakultas Pertanian, Universitas Padjadjaran, Jl. Raya Bandung, Sumedang KM 20, Jatinangor 45363 \\ email: ${ }^{1}$ lukman.hakim.sp.mp@gmail.com; ${ }^{2}$ tomyp1973@yahoo.com
}

\begin{abstract}
The objectives of this study is to design a model of integrated supply chain management of potato agribusiness in an effort to increase revenue and bargaining position of farmers in Aceh Province. The method applied to achieve these objectives was the methodology of system dynamics. Formulation of the models was conducted by using Vensim DSS Software, followed by simulation. The result of this study showed the role of five major scenarios which were important to actualize the integrated supply chain management of potato agribusiness in Aceh Province, those were: scenario 1, increasing the productive land area, resulting in the increasing of production volume; scenario 2, using the certified potato seed named "umbi G2", generating the higher level of production; scenario 3, providing the certified potato seed based on the needs, showing that the quantity of production increased; scenario 4 , shortening the payment receivables interval of farmers and cooperatives, which showing the increasing of cash amount; scenario 5, doing certification to the potato from synergistic partnerships farmers, showing the increasing of acceptance, profitability, R/C, and cash.
\end{abstract}

Keywords: system dynamics, supply chain management, potato agribusiness

\section{Introduction}

Food has a promising business prospects over time and is a sustainable business in the future. The issue of food is one of the national problem. Food supplies are very relevant to the welfare issues and survival of the Indonesian nation. The Government awares that in order to face the challenges of the global market, Indonesia must change the pattern of subsistence farming developed into a service oriented business. Advanced agriculture-oriented businesses require high efficiency, market-oriented to quality and competitive prices in sufficient quantity, timely continuity of supply for the domestic market and international market.

Supply chain management of agricultural products is different with the supply chain management for other manufactured products for some of the typical characteristics, namely:

(1) agricultural products are perishable, (2) the process of planting, growing and harvesting depends on the climate and season (3) yields have shapes and sizes, (4) the product is "kamba" agricultural products which is difficult to handle (Austin, 1981; Brown, 1994), as well as reduce the uncertainty in the business. All of these factors are used into consideration to design and analyze the supply chain of products which makes the supply chain management of agricultural products become more complex than chain management in general.

Potato (Solanum tuberosum L.) is one of horticultural commodities. Potato is prospectively developed as demand continues to increase in line with population growth, as a highly nutritious food, raw material for food processing industry, non-oil export commodities, and as a source of farmers income. It has the highest and efficient energy and protein productivity/hectare/unit time, and can be planted on the condition of altitude, latitude and climate that is wider than the other major staple crops.

Received: October 28, 2016, Revision: March 30, 2017, Accepted: May 19, 2017

Print ISSN: 0215-8175; Online ISSN: 2303-2499.

Accredited by DIKTI. SK Kemendikbud, No.040/P/2014, valid 18-02-2014 until 18-02-2019, Indexed by DOAJ 
Based on the basic pattern of regional development in 2014, several commodities have been established as the leading commodity areas, one of which is potato. Potato production center in Aceh Province located in Central Aceh and Bener Meriah. Both regions have the total land area of 79.217 hectares. As many of 3.228 hectares (approximately $4 \%$ of the total area) are planted with random vegetables, and a new portion of land area (1.500 hectares) is planted by the granola potato (Aceh Department of Agriculture, 2014).

Potato cultivation in Aceh province is still experiencing a variety of problems, thus not achieving the optimum. It can be observed from the low level of productivity of potato per hectare of new land, that is only capable of producing an average of 15 tons, which amount is still below the potential value of the effective potato production which ranges between 30-40 tons/ha. Meanwhile, the land area planted is still limited, which is in average of 0.5 hectares/farmer. This also contributes to the low level of productivity, coupled with the difficulties faced by farmers to obtain certified seed because of its availability is currently only able to meet the needs of farmers seedlings between $60-70$ percent which makes farmers are still experiencing a shortage of supply of seeds around 700800 tons/mt. Insufficient number of seeds also affects the expensive purchase price of seedlings ( $R p$ 18,000-Rp. 22,000, per $\mathrm{kg}$ ), thus increases the cost of production. On the other hand, the function of the extension services has not been implemented effectively (0-2 times/year), which adversely affects the control of farmers on potato cultivation technology (Kasimin, 2009).

In addition, the slow optimization of potato cultivation in the province of Aceh can also be observed on the welfare of farmers which has not been satisfied. Income enjoyed by farmers is still relatively low, at only average of Rp.15 million/ha. This condition occurs as a result of the insufficient support of government to help farmers market their crops. Farmers find it difficult to get access to the market and price information, which impacts on the low selling price of potato (Rp $3.000 / \mathrm{kg}$ ) and high marketing costs (>50\%). Capital constraints also experience by farmers. Farm loan programs initiated by local governments is not adequate ( $<2$ Source), so that farmers are not free to expand the market (Kasimin, 2009).
The low of productivity is inseparable from the constraints that occurs in managing the farming of potato, such as technology application and post-harvest, especially in the availability and quality of seeds, quality of intensification, inefficient system of farm production, the weak performance of the entrepreneurial community, the lack of institutional support, institutional extension, and the system marketing management. The diversity of the issues are not independent, but interrelates with each other despite the different contributions.

The effort of system dynamics modeling application in supply chain management integrated agribusiness potato in Aceh Province raises some interesting questions to be studied, namely: Is agri-business supply chain management model integrated potato can be applied in Aceh that has different geographic characteristics, social and cultural rights? Can the model application of integrated potato agribusiness supply chain increase the added value, competitiveness and bargaining power of farmers? Who will get the most benefit from the introduction of the supply chain management of integrated agribusiness potato in Aceh? What factors determine the success of implementation of the model?

In an attempt to answer these questions, it is necessary to study the system dynamics modeling in supply chain management integrated agribusiness potato in Aceh. The use of system dynamics approach in this study, is based on the conviction that this methodology has several advantages compared with conventional forecasting methods (Lyneis, 2000). The advantages of this approach can be described as follows; (1) provides a reliable estimate of the statistical model; (2) provides a way to understand the causes of behavior, detects the early changes in the structure and determines the factors that predict the behavior of significant and sensitive; and (3) allows determination of plausible scenarios as input for decisions and policies.

Based on the literature research results in the form of books, journals and scientific articles, it is known that specific research on the systems dynamics modeling on supply chain management integrated agribusiness potato in Aceh Province has so far not been reported. In connection with that, the research must be done to analyze in depth the role of each actor in the model and their interactions with one another in an effort to 
improve the bargaining position of potato farmers in Aceh.

\section{Supply Chain and Business Cluster Development}

According to Stock and Lambert (2001) supply chain management business process requires major activities include: customer relationship management, customer service management, demand management, order fulfillment, manufacturing flow management, procurement, development and commercialization of products, and the rate of return.

According to Watanabe (2001), supply chain management is a concept or mechanism to increase the total productivity of companies in the supply chain by optimizing timing, location, and quantity of the material flow. A supply chain refers to a complex network of relationships in which the organization maintains with his business partner to get the production source in distributing it to consumers. According to Chopra (2001), the objective of any supply chain is to maximize the value generated overall. Integrated supply chain will enhance the overall value generated from the supply chain.

According to Vidal and Goetschalckx (1997), supply chain design requires decision relating to the location, suppliers, transportation management, and supply of raw materials. Based on this, the supply chain management must be able to integrate these aspects in its decision making process.

According to Porter (1998), cluster is geographic concentration of companies and institutions interconnected in a particular sector. They are related because of togetherness and complementary. Cluster encourages the industry to compete with each other. Besides industries, the government and industry that provide support services such as training, education, information, research and technology support, also includes in the cluster. Meanwhile, according to Schmitz (1997), cluster is defined as a group of companies gathered in one place and work in the same sector. While Enright (2001), defines cluster as companies similar/same or interrelated, gather in a specific geographic boundaries.

In the development of the region, it is known the diversed types of cluster. Two of the most common categories are regional cluster and business cluster. Regional cluster is a group of companies that appears in/ formed by the boundaries of a particular economy. This cluster gains the advantage of the interaction between the company, the use of shared assets, and/or the provision of shared services. Business cluster is a group of companies that despites having different mutual business but has activities that are interconnected, and together creates synergy and mutual learning process. Related to this study, the type of cluster that is applied to agribusiness development model is the potato business cluster.

Based on the formulation of changes, things that need to be implemented in a cluster collaborating with multiple parties should be optimized through actively controlled activities, more intensive facilitation, dissemination and sharing of information relevant to cluster development through effective meetings, mentoring, strengthening cooperative institutions, business relationship management with stakeholders, and training management (Andayani, et al. 2016).

Setiawan (2015) elaborated in his research that the independence of young businessmen of agriculture is quite poor, particularly in aspect of quality and competitiveness. He suggested several collaborative strategies, which are: (1) to improve the practical ability of young executives to be better able to adapt and ready to start his business. (2) improving innovation and agribusiness environment, creating alternative market to increase competitive ability so as to give positive feedback to the independence of young businessmen in agribusiness field. (3) to create a creative and conducive climate and environment in rural areas for the process of strengthening productivity of young agribusiness entrepreneurs.

\section{System Dynamics Methodology}

The method applied in this study is the methodology of system dynamics, which is a modeling approach based on systemic thinking and use perspective based on the feedback information and delays, to understand the dynamics of complex behavior of a physical system, biological systems, and social systems, which occurred in the management chain agribusiness supply of potato. Potato production center in Aceh Province, namely Central Aceh and Bener Meriah, are chosen to be the working area of the study.

The identification of the need for supply 
chain management model of agribusiness potato is done through literature and interviews with experts from stakeholders, namely practitioners and policy makers involved in the procedure of input supply, production, and marketing of potato output. Data collected consist of primary and secondary data. The primary data obtained through observation, in-depth interviews with respondents, as well as the activity of FGD (Focus Group Discussion), while secondary data obtained through the study of literature from various sources of literature, books, scientific journals, and a variety of publications related to this research. Formulation of models is made by software Veneta Simulation (Vensim DSS), which is followed by simulation.

\section{Strategy of Potato Agribusiness Sup- ply Chain Development}

Potato supply chain committed in Aceh so far has not been able to produce satisfaction for the actors involved. Potato agribusiness development in Aceh, is carried out as a solution to solve all the complex problems particularly in the potato commodity, which is expected to increase the income of farmers and entrepreneurs engaged and is able to move the wheels of the local economy

The common model of potato supply chain starts at the stage of input supply, production, harvest and post-harvest, and marketing. Potato supply chain in Aceh is a complex network, since it involves a variety of actors. However, activity in the agribusiness supply chain of potato will apply the integrated system, with the relationship of the various actors involved in every activity of the supply chain.

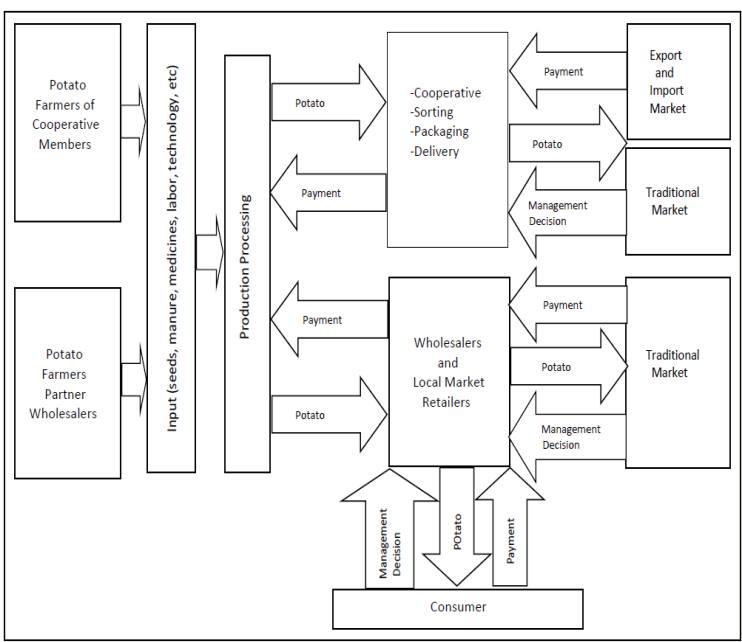

Figure 1. Common Model of Potato Supply Chain
The common model of potato supply chain is developed into a causal diagram to understand the complexity of a phenomenon in the agribusiness supply chain management of potato, which refers to a common model components and research purposes, so it will be a limitation on the system causal diagram.

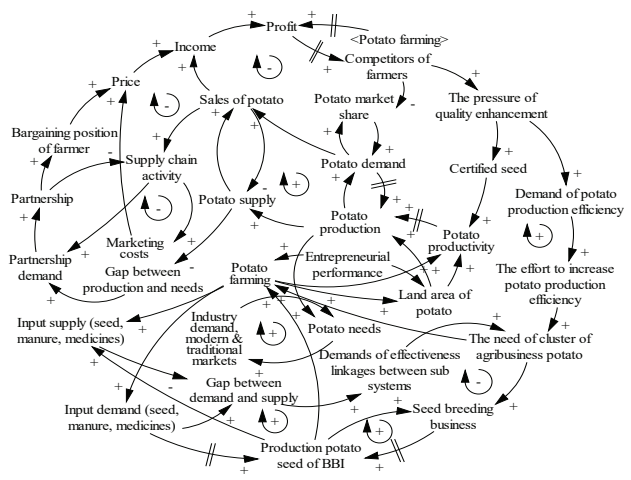

Figure 2. Diagram of Cause and Effect of Supply Chain of Agribusiness Potato

The interaction between variable and complex causality of potato agribusiness supply chain structure, requires the understanding of phenomenon should be developed from a causal diagram into simulation models in the form of sub model diagram which is the result of the flow chart (flow diagram) development. in the sub model diagram, it is can be identified and developed the physical structure and the decisions that are forming behavior dynamics agribusiness potato supply chain in Aceh.

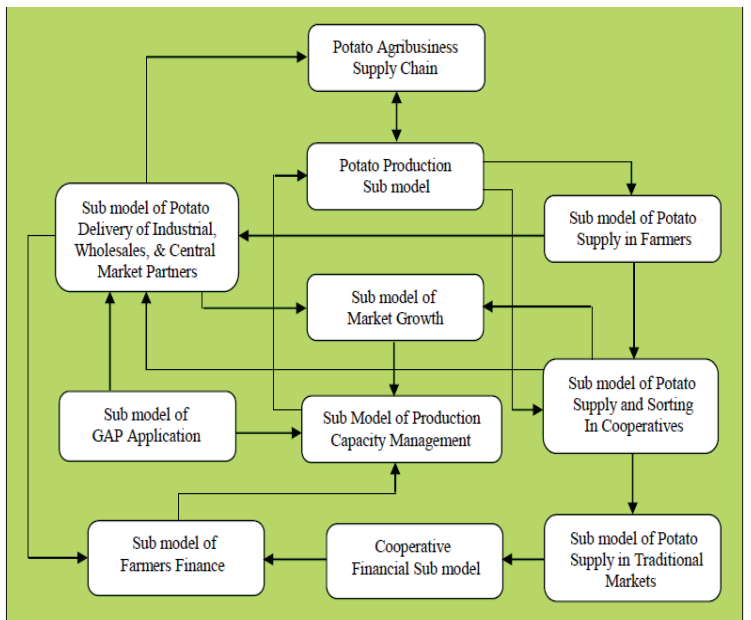

Figure 3. Diagram of Relationship between Sub Model Potato Supply Chain Sustainability

The physical structure is represented by the flow of material (potato) and the flow of money, while the decision structure is 
represented by the flow control information into material and cash flow decisions. Links between sub-models on agribusiness potato supply chain, which is a novelty of this study, as well as a differentiator with other research, can be seen in Figure 3.

\section{Scenario of Increasing the Number of Productive Farm Land Area of Potato}

Scenario 1 represents the development of the vast amount of productive land farming of farmers who become cooperative partners and the industry. This means that the vast amount of productive land farming of potato have increased. The goal of increasing the amount of productive land area is to increase the production of potato of farmers as cooperative partners so as to continuously meet the demand of the industry, the domestic and export markets. Furthermore, the observation and comparison of the results of the application of these scenarios are being done.
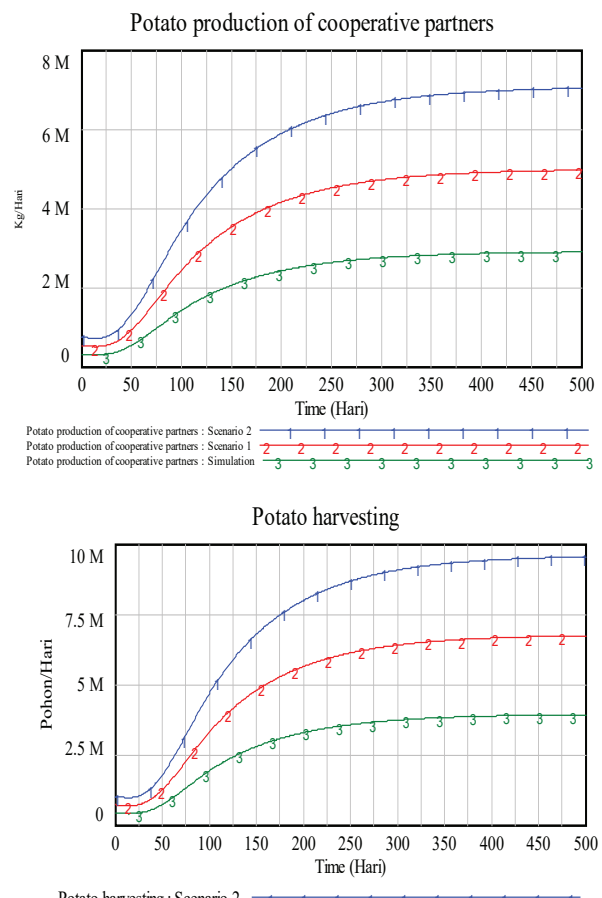

Potato harvesting : Scenario 2

Potato harvesting : Scenario

Potato harvesting: Simulation

Figure 4. Scenario 1 Production and Potato Harvest of Cooperative Partner

Figure 4 shows that the higher the productive land area, the higher the level of production is generated. This is due to the fertile land that would meet the needs of the nutrient and high productivity, so that any increase in the land area will be followed by increased production and harvesting. Through increased production output is expected to increase profits and income derived by farmer of cooperative partners.

\section{Scenario of Increased Productivity Through the Use of Certified Seed Potato}

In the second scenario, the use of certified seed potato is done. Farmers use bulbs G4 and G3 in the actual condition, meanwhile, in this scenario, the bulb G2 is used as the seed. It is based on the results of research conducted in Pangalengan West Java province, that the use of bulb G2 could increase the productivity of potato which reached 34.41 tons/ha. The use of bulb G2 is done to improve the production of potato so that the level of profitability and farmers' income will increase.

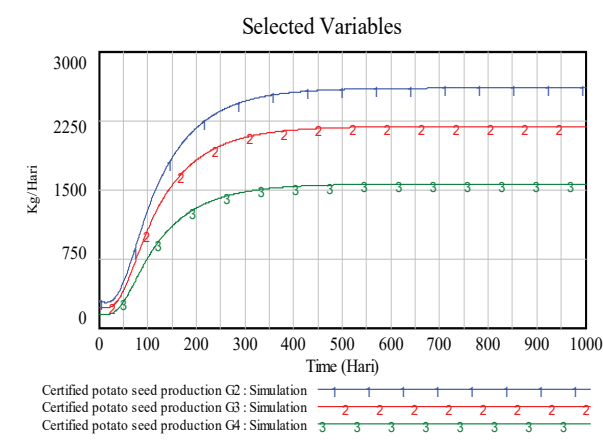

Figure 5. Scenario 2 Using Bulbs G2, G3, and G4 Certified against Production

Based on Figure 5, the results of the scenario using potato seed tubers G2 effectively managed to increase the productivity of potato significantly, compared with production using potato tuber G3 and G4.

\section{Scenario of Availability of Certified Seed Potato for Farmers}

In the third scenario, the availability of certified seed of potato is managed. In the actual condition, the availability of seed only reachs 1,200 tons/year. In this scenario, the number of certified seed availability (G2, G3, and G4) is increased to 3,600 tons/year. By this way, the level of production is expected to increase.

Figure 6 shows that the higher availability of certified seed potato stock, the higher the level of production of potato farmers produced. Through increased production output, it is expected to increase profits and income of farmers. 
Stock availability of certified potato seed

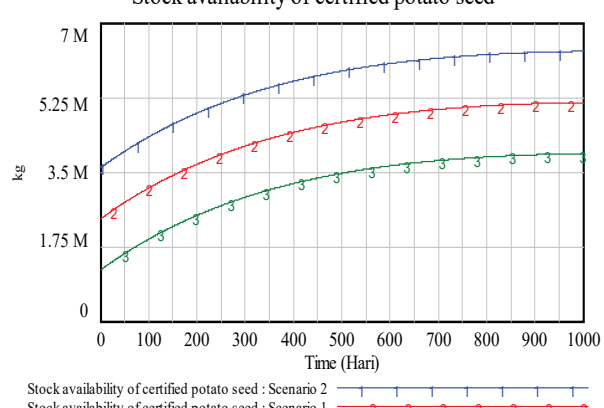

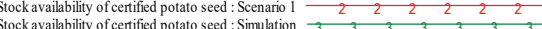

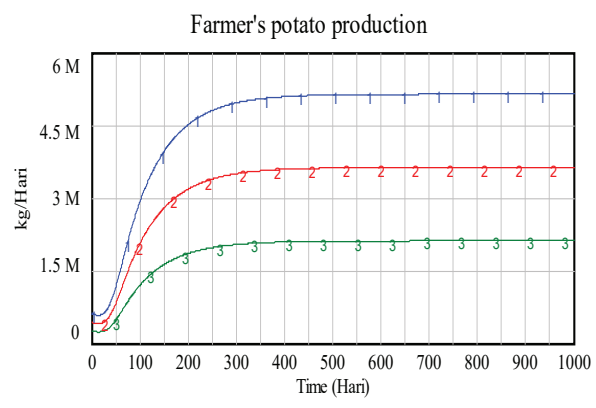

Farmer's potato production: Scenario 2

Farmer's potato production: Scenario

Farmer's potato production: Simulatio

Figure 6. Scenario 3 Stock Availability of Certified Seed Against Production

\section{Scenario of Payment Time Delay of Accounts Receivable Cooperatives and Farmers Partners Industry}

One of policy intervention that can be applied to help farmers improving productivity is to shorten the term of payment from 30 days (in the actual condition) to 3 days. The relatively long repayment period of industry to farmers through cooperatives can lead to disruption of farmers'liquidity to manage further production. Thus we need a policy in overcoming the liquidity constraints that is through cooperatives, banking financial institutions and non-banking. The scenario results of shortening the delay time of cooperatives receivable payments and farmer members by the industry can be seen in Figure 7.

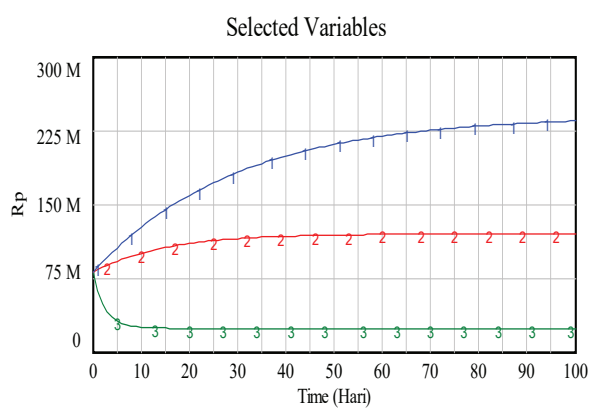

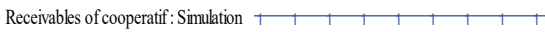
Receivables of cooperative 1: Simulation $\begin{array}{llllllll}2 & 2 & 2 & 2 & 2 & 2 & 2\end{array}$

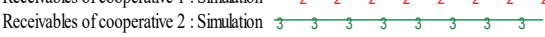

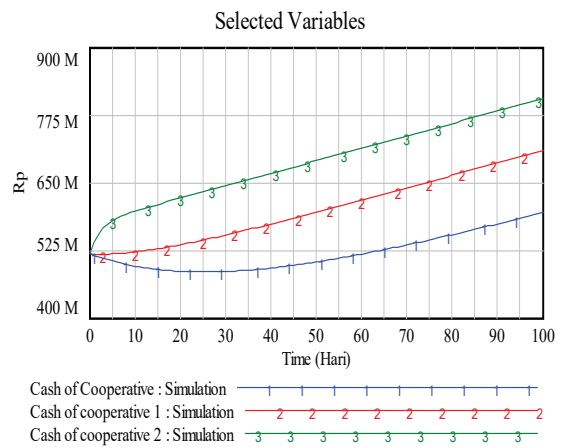

Figure 7. Scenario 4 Delay Time of Cooperatives Receivables to Cooperative Cash

The results of Scenario 4 gives information that cooperatives cash have a tendency to rise to a higher trend compared to prior condition. This indicates that the scenario is effectively a positive impact of increased cooperatives cash so that cooperatives can be immediately paid receivables of farmers' cooperative partners and take advantage of the venture capital towards other productive sectors.

The impact of the delay in payment from industry to the cooperative is automatically hampering the cooperative payments to farmers. This of course makes loss of farmer because it would obstruct the fund utilization.
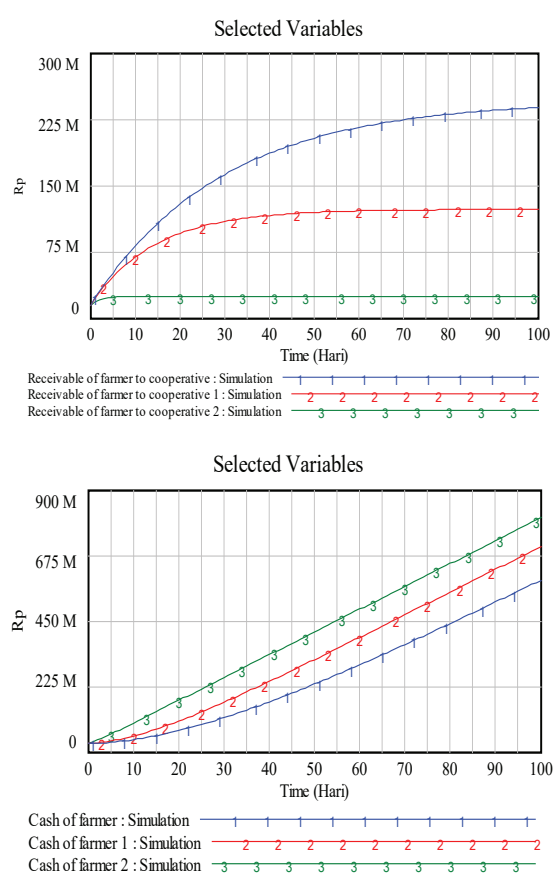

Figure 8. Scenario 4 Delay Time Cash Receivable Against Farmer's Cash

The results of Scenarios 4 in Figure 8, shows that farmers's cash have a tendency 
to rise to a higher trend compared to the previous farmer's cash. This indicates that delay time scenarios of payment of 30 days to 3 days, effectively gives positive impact in the form of an increase in cash of farmers so that farmers have the opportunity to increase revenue by leveraging capital to other productive business units before next potato planting season. It is expected to be able to increase profits and income of farmers.

\section{Potato Certification Scenario of Farmers of Cooperative Partners}

The goal of this scenario is to obtain the lowest level certification of safe product for consumption. Pesticides are used in the cultivation of potato, but it is still within safe limits for consumption. It costs Rp. 25.000.000,- to obtain a lowest level certificate of food safety, meanwhile, each member of cooperatives only charged with the cost as many as Rp. 250.000,-. Thus the potato certification scenario, changes the parameter on the selling price of potato, because potato that has been certified is expected to obtain higher selling prices due to its safer for consumption. Selling price parameter value is changed in this scenario according to the demands of farmers for

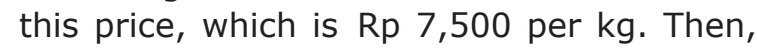
the structure of certification cost is added in the financial model of farmer cooperative partners.

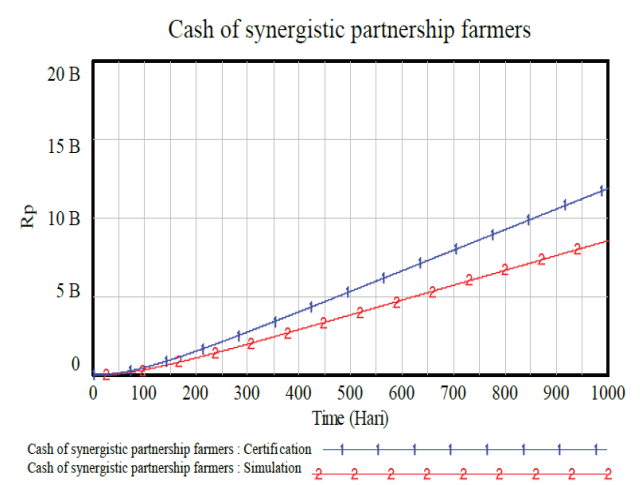

Figure 9. Scenario 5 Cash of Farmers Cooperative Partner Before and After Potato Certification

Figure 9 gives information that the cash of farmer cooperative partner (certification) has increased. This happens because the revenue of farmers after certification was higher, so as to cover the costs incurred for the certification process. The certification process of food safety gives benefit to the consumers and also to the farmers as providers of raw materials for processed food products. An increase in profits on farmer cooperative partners who have been certified can be seen in Figure 10.

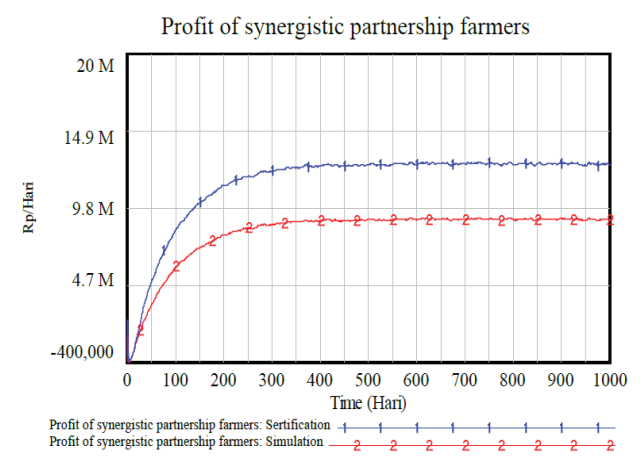

Figure 10. Scenario 5 Advantages of Farmers Cooperative Partner Before and After Certification

Certified potato has better quality than the uncertified product, so it has a high commodity price. This resulted in an increase revenue and profit earned by farmers. The increasing revenue of farmer cooperative partner after the certification process can be seen in Figure 11.

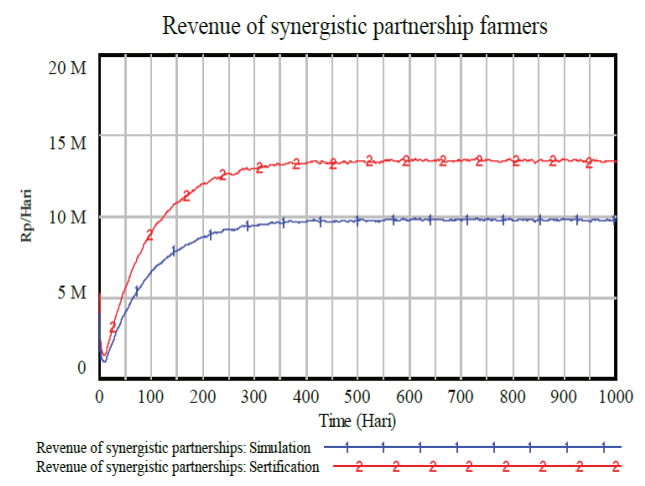

Figure 11. Scenario 5 Admission Farmers Cooperative Partner Before and After Certification

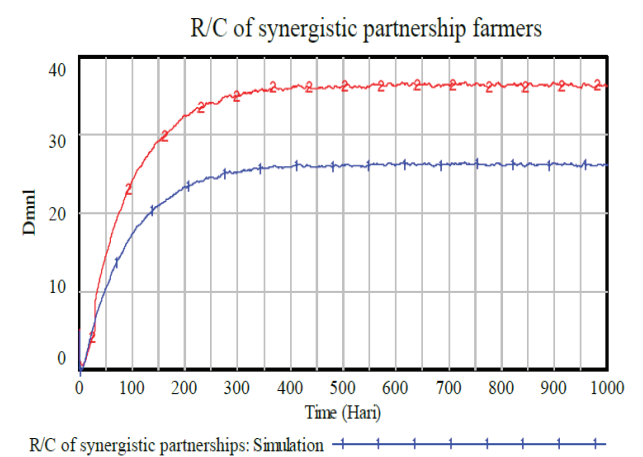

Re of

Figure 12. Scenario $5 \mathrm{R} / \mathrm{C}$ of Farmers Cooperative Partner Certification Potatoes Before and After Certification 
The number of $\mathrm{R} / \mathrm{C}$ of farmers that have certified product will increase with the increasing of acceptance, as $\mathrm{R} / \mathrm{C}$ is the ratio of the admission fee. In Figure 12, the R/C level of farmers with certified product is higher than those who have not got certified yet. Thus, certification can contribute to the success in the development management of integrated potato agribusiness supply chain in Aceh.

\section{Design of Integrated Supply Chain Management of Agribusiness Potato and Policy Implications of Research}

The result of behavior understanding of the above scenarios indicates that improvement of supply chain management of agribusiness potato needs to be done to develop the potato commodity in the future. Engineering is done by considering both the potential of the natural resources and human resources. The process of supply chain management engineering in this study to raise the agribusiness potato development is done by redesign the general model.

The technological and institutional innovation are given in the scenario or policy proposals recommendation, and also increases the stakeholders involved in the system so that it looks more and more complex (Figure 13). Network structure in the supply chain should be able to convey the material flow, cash flow, and the flow of right quantity, right quality, right time, right price, transparent, and sustainable information, so that it can satisfy the consumers (Perdana, 2009). Similarly, it is applied in the network of supply chains in cluster development of agribusiness potato. Innovation and technology learning in supply chain management of agribusiness potato are obtained from stakeholder services. Therefore, it is necessary to engage stakeholders in the supply chain management in the cluster to be able to support a policy that has been in the scenario.

The information obtained based on the simulation results of scenarios on supply chain management of agribusiness potato, is that the policy that can be applied to increase revenue and bargaining position is the implementation of the whole five scenarios. Thus, the design of the supply chain management model of agribusiness potato should be followed by technological innovation and institutional innovation model, that is by regulating the relationship between farmers, cooperatives, industry, and other relevant agencies in the form of collaboration.
In an effort to implement the institutional innovation, cooperative institutionally strengthened both the role and function that can support the cluster development of agribusiness potato. This is reinforced by Teekasap (2009), who explained that the cluster will develop more quickly and grow larger if one of them is a training institute for the development of clusters in it. Under these conditions, the supply chain management model for cluster development of agribusiness potato is capable of producing a sustainable and efficient system in accordance with the purpose of reducing costs clusters, creating innovation, and improving productivity.

Supply chain management model of agribusiness potato that is efficient and sustainable requires transparent information flow, so it is conducted technical assistance, managerial, institutional, access to technology, financing and market through the facilitator managed by the Center of Research and Development for Innovation and Institutional, LPPM Unsyiah. The facilitator is a bridge between farmers, farmers' groups, cooperatives, and industrial companies.

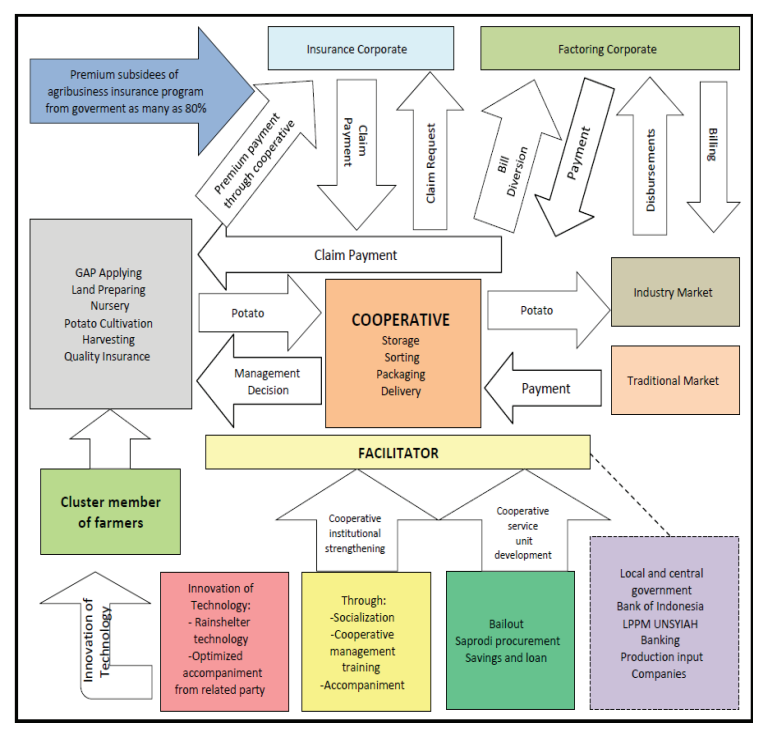

Figure 13. Design of Supply Chain Management in Integrated Cluster Development of Agribusiness Potato

In an effort to strengthen the supply chain management of agribusiness potato so that it can increase revenue and bargaining position of farmers, LPPM Unsyiah should cooperate with the multistakeholder as stakeholders in the cluster development of agribusiness potato, such as banking, insurance, factoring, other market participants and also increase the role of government as this can not be overcome by the interaction between small 
farmers and industrial companies only, so that it can be said that the partnership in cluster development of agribusiness potato is the network level because it involves multistakeholder network in a variety of interests in the cluster. At this level there are rules of governance interaction between small farmers and industrial enterprises with stakeholders that aims to improve the access of small farmers to agro input, technology, financing, and access to the market (Perdana, 2012).

\section{Conclusions}

In an effort to develop the integrated supply chain management model of agribusiness potato which is expected to improve the bargaining position of farmers in the Province of Aceh, the five development scenarios are implemented, consisting of: (1) increasing the productive farm land area, resulting in the increasing of production volume. (2) using the certified potato seed named "umbi G2", generating the higher level of production. (3) providing the certified potato seed based on the needs, showing that the quantity of production increased. (4) shortening the payment receivables interval of farmer cooperatives and industry partners, which showing the increasing of cash amount. (5) certifying the potato of cooperative member farmers, showing the increasing of revenues, profits, $\mathrm{R} / \mathrm{C}$, and farmer's cash, as the impact of increasing the bargaining position of products.

Based on the simulation results of scenarios on supply chain management, of agribusiness potato, it is obtained that the policy which can be applied to increase revenue and bargaining position is the implementation of the five scenarios. Thus, the design of the supply chain management model of agribusiness potato should be followed by technological innovation and institutional innovation model, that is by regulating the relation between farmers, cooperatives, industry, and other relevant agencies in the form of collaboration In an effort to implement the institutional innovation, cooperative institutionally strengthened both the role and function that can support the cluster development of agribusiness potatoes.

Model of supply chain management of agribusiness potato that can be implemented and used as reference in the preparation of policy measures in formatting the cluster of agribusiness potato in Aceh is a model of management and institutional innovation, which can accelerate the development of potato commodity, increase revenue and bargaining position of farmers, and be able to drive the wheels the regional economy.

Due to the application of production input in farming potato in the research area is not optimal because of the constraints of capital, the government is expected to provide capital support in the form of noninterest loan or low interest loan, so farmers can improve the system of potato cultivation and reduce dependence on traders as the owner of capital, thereby increasing the bargaining position of farmers in marketing their products.

Coaching in terms of mastery of cultivation technology, marketing management, entrepreneurship, and access to market information should be given to farmers, as part of the process of improving their bargaining position.

Policy formulation should be done by focusing on the needs of farmers as a core part of the cluster, which is expected to produce effective policies, targeted, and have optimal performance in practice.

\section{Acknowledgment}

This article is part of research entitled "System Dynamics Modelling on Integrated Supply Chain Management of Potato Agribusiness" The writer would like to thank Directorate General of Higher Education (Dirjen Dikti) who has financed the research. The writer would also like to thank Syiah Kuala University who has given the opportunity to do the research and Agriculture Faculty of Padjadjaran University.

\section{References}

Aceh Department of Agriculture. (2014). Data of Harvested Area Development and Production of Potato Commodity. Banda Aceh.

Andayani, S.A., Sulistyowati, L., Perdana, T. (2016). The Development of Red Chili Agribusiness Cluster with "Soft System Methodology" Approach in Garut. Journal of Social and Development "MIMBAR". Vol. 32, No. $2^{\text {nd }}$ (December, 2016), pp. 302-310.

Austin, J.E. (1981). Agroindustrial Project Analysis. Maryland: The John Hopkins University Press.

Brown, J.G. (1994). Agroindustrial Investment and Operations. Washington: The World 
Bank.

Chopra, Sunil, Meindell, P. (2001). Supply Chain Management: Strategy, Planning, and Operation. New Jersey. Prentice Hall.

Enright, M.J. (2001). Regional Clustering in Australia. Australian Journal of Management, Vol. 26. Special Issue, August 2001. The Australian Graduate School of Management.

Kasimin, S. (2009). "Model Pengembangan Agribisnis Kentang di Provinsi Nanggroe Aceh Darussalam Melalui Analisis Keterkaitan Produk dan Pelaku". Disertasi. Program Pascasarjana Universitas Padjadjaran. Bandung.

Lambert, D.M., Cooper, MC. (2001). "Issue in Supply Chain Management". Industrial Marketing Management. Vol. 29:1, 65-83.

Lyneis, James, M. (2000). System dynamics for market forecasting and structural analysis. Massachussetts: The MIT Press.

Perdana, T. (2009a). Pemodelan Dinamika Sistem Rancang bangun Manajemen Rantai Pasokan Industri Teh Hijau. Disertasi, Program Studi Teknologi Industri Pertanian Sekolah Pascasarjana IPB, Bogor.

Perdana, T., Kusnandar. (2012b). The Triple Helix Model for Fruits and Vegetables Supply Chain Management Development Involving Small Farmers in Order to Fulfill the Global Market Demand. Procedia-
Sosial and Behavioral Sciences 52 (2012) 80-89, Elsevier. www.sciencedirect.com

Porter, M.E. (1998). Cluster and the New Economics of Competition. Reprint 98609. Harvard Business Review, 68 (2): 84-85.

Schmitz, Robert. (1997). Principles for Promoting Clusters and Networks of SMEs. UNIDO. Austria.

Setiawan, I., Sumardjo, Satria, A., Tjitropranoto, P. (2015). Strategi Pengembangan Kemandirian Pelaku Muda Agribisnis "Brain Gain Actors" di Jawa Barat. Jurnal Sosial dan Pembangunan "MIMBAR". Vol. 31, No. 2 (Desember, 2015): 409-418.

Teekasap, P. (2009). Cluster Formation and Government Policy: System Dynamics Approach. In Proceedings of the 27th International Conference on the System Dynamics Society (An. Ford, D.N. Ford and Ed. G. Anderson Ads.), System Dynamics Society, Albuquerque, New Mexico, USA.

Vidal, C.J, Goetschalckx, M. (1997). Strategic Production-Distribution Models: A Critical Review with Emphasis on Global Supply Chain Models. European J. Operational Research 98:1-18.

Watanabe, R. (2001). Supply Chain Management Konsep dan Teknologi. Usahawan No. 02 Tahun XXX Februari 200, halaman 8-11. 